\title{
Pemberdayaan Masyarakat melalui Inovasi Perencanaan Pembangunan berbasis 4R (Rembug, Rencana, Realisasi dan Rawat) di Desa Cilangkap Kecamatan Wanasalam sebagai Pilar Utama Kebijakan Partisipatif dan Gotong Royong
}

\author{
Ahmad Sururi, Rahmi Mulyasih \\ Universitas Serang Raya \\ sururiahmad20@gmail.com
}

\begin{abstract}
Participatory development planning and gotong royong in encouraging the strengthening of village officials and empowering rural community through innovation of development planning policy based on the concept of Rembug, Plan, Realization and Rawat is a grand design of development planning by placing society as center of development as well as actor has a major role in village development planning by prioritizing local resources and potential based on local wisdom. The main focus of this dedication is to provide socialization and mentoring both theoretical and practical in the development of the concept of development planning policy based on the concept of $4 \mathrm{R}$ namely Rembug, Plan, Realization and Rearing which aims to empower and improve community skills in preparing development planning with priority resources and local potential which are owned. The method used is participatory village assessment and Participatory Learning and Action by emphasizing on the 4R concept of rembug, plan, realization and care. Based on the results obtained from the mentoring are: 1) Cilangkap Village community as a community service partner has a great response and enthusiasm in the process of mentoring development planning. This can be seen from the number of community attendance in the village meeting villagers with an average attendance of $60 \%$ of the total number of households in each village; 2) As one of the villages that are still relatively poor, the community's enthusiasm in following the mentoring program needs to be appreciated as part of the community's awareness of the importance of development designed from, by and for the community; 3). The ability of the community to design the development planning through the formation of development planning organizations, independent village survey activities and rembug activities, plans, realiation and care can be run well although with all the limitations owned but not reduce the substance of the growth process of community empowerment and community motivation in the development planning activities.
\end{abstract}

Keywords: Community Empowerment, development planning

\section{Pendahuluan}

Perwujudan dimensi pembangunan yang berbasis pemerataan dan kewilayahan disertai membangun Indonesia dari pinggiran dengan memperkuat Daerah-daerah dan Desa dalam kerangka Negara Kesatuan merupakan amanat Nawacita. Daya saing desa dengan potensi lokal yang beragam memungkinkan setiap desa untuk berkembang sesuai dengan agenda perencanaan pembangunan dengan berbasiskan kearifan lokal. Dalam amanat Nawacita disebutkan bahwa pembangunan Desa

Volume 1, Number 2, November 2017 | 218 Pemberdayaan Masyarakat melalui Inovasi Perencanaan Pembangunan berbasis 4R (Rembug, Rencana, Realisasi dan Rawat) di Desa Cilangkap Kecamatan Wanasalam sebagai Pilar Utama Kebijakan Partisipatif dan Gotong Royong Ahmad Sururi, Rahmi Mulyasih 
dan kawasan perdesaan dilakukan melalui pemenuhan standar pelayanan minimum khususnya di desa-desa tertinggal dan perbatasan, penguatan tata kelola pemerintahan Desa yang baik, mewujudkan desa berkelanjutan dan membangun keterkaitan desa-kota melalui: pengembangan kegiatan perekonomian hulu-hilir dan industrialisasi perdesaan khususnya di desa-desa yang telah berkembang dan mandiri yang terkait dengan industri di kota-kota sedang dan kecil pada pusat-pusat pertumbuhan terdekat.

Karakteristik Desa dengan ragam potensi lokal yang dimiliki dan dukungan masyarakat yang masih mengedepankan nilai-nilai budaya lokal dan semangat kebersamaan partisipatif, kepercayaan, toleransi serta gotong royong merupakan modal sosial yang sangat penting dalam mendorong proses pembangunan kawasan perdesaan. Perwujudan modal sosial sebagai segala sesuatu hal yang berkaitan dengan kerjasama dalam masyarakat atau bangsa untuk mencapai kapasitas hidup yang lebih baik, ditopang oleh nilai-nilai dan norma yang menjadi unsur utama seperti trust, keimbalbalikan, dan aturan kolektif. ${ }^{1}$ Dan hal tersebut dapat terwujud dengan dukungan dari berbagai pihak dalam mendorong modal sosial perdesaan yang telah dimiliki yang dikolaborasikan dengan pemberdayaan masyarakat.

Untuk mendorong perubahan paradigma pembangunan desa yang selama ini terpusat atau menempatkan desa sebagai objek menjadi desentralisasi atau menempatkan desa sebagai subjek maka diperlukan pemberdayaan masyarakat yang inovatif melalui grand design perencanaan pembangunan partisipatif yang memberikan prioritas dan space bagi masyarakat untuk berpartisipasi dan berkembang sesuai dengan karakteritsik dan potensi lokal yang dimiliki. Dampak dan manfaat yang diharapkan dari inovasi pemberdayaan dan penerapan grand design perencanaan pembangunan partisipatif adalah penguatan kapasitas masyarakat desa melalui aktor-aktor kebijakan pembangunan sebagai subjek formulasi kebijakan.

Perencanaan pembangunan desa sebagai salah satu kewenangan pemerintah desa sebagaimana diatur dalam Undang-undang Nomor 6 tahun 2014 tentang desa disusun sesuai dengan perencanaan pembangunan Kabupaten/Kota yang disusun secara berjangka untuk merumuskan Rencana Pembangunan Jangka Menengah Desa untuk jangka 6 (enam) tahun dan Rencana Kerja Pemerintahan Desa (RKPD) sebagai penjabaran dari RPJMDesa untuk jangka

1 J Hasbullah, Social Capital (Jakarta: United Press, 2006).

Volume 1, Number 2, November 2017| 219

Pemberdayaan Masyarakat melalui Inovasi Perencanaan Pembangunan berbasis 4R (Rembug, Rencana, Realisasi dan Rawat) di Desa Cilangkap Kecamatan Wanasalam sebagai Pilar Utam a Kebijakan Partisipatif dan Gotong Royong 
waktu 1 (satu) tahun. ${ }^{2}$ Perencanaan pembangunan desa sebagai salah satu masukan dalam perencanaan pembangunan Kabupaten/Kota disusun melalui mekanisme musyawarah perencanaan pembangunan desa yang diselenggarakan oleh pemerintah desa. Dalam Musyawarah perencanaan Pembangunan Desa ditetapkan prioritas, program, kegiatan, dan kebutuhan Pembangunan Desa yang didanai oleh Anggaran Pendapatan dan Belanja Desa, swadaya masyarakat Desa, dan/atau Anggaran Pendapatan dan Belanja Daerah Kabupaten/Kota.

Meskipun musyawarah perencanaan pembangunan desa sudah dilaksanakan akan tetapi masih terdapat berbagai permasalahan terkait dengan aspek pengambilan keputusan perencanaan pembangunan desa yang masih bersifat sentralistik dimana masih besarnya pengaruh kepala desa dan aparat desa dalam pengambilan keputusan sehingga keputusan yang dibuat belum mempunyai dampak terhadap peningkatan kualitas dan akses terhadap pelayanan dasar masyarakat desa. Musyawarah perencanaan pembangunan desa sebagai forum dialog antara warga dan aparat pemerintahan desa dalam membahas permasalahan-permasalah strategis pembangunan perdesaan berjalan seremonial dan hanya sekedar menggugurkan kewajiban bagi aparat pemerintah desa. Kehadiran masyarakat pada musyawarah desa diposisikan secara pasif dan hanya mendengarkan program-program kerja pembangunan desa yang telah diinisiasi oleh aparat pemerintahan desa. Masyarakat belum secara aktif dan diikutsertakan mengemukakan permasalahan-permasalahan yang selama ini menjadi hambatan-hambatan.

Disisi lain musyawarah perencanaan pembangunan desa hanya menjadi forum perencanaan pembangunan perdesaan yang bersifat jangka pendek dan tidak melibatkan masyarakat desa dalam aspek perencanaannya. Hal ini disebabkan karena agenda perencanaan pembangunan desa tidak disusun berdasarkan aspirasi masyarakat desa melalui forum-forum musyawarah warga desa di tiaptiap Rukun Tetangga (RT) dan Rukun Warga (RW) sehingga urgensi perencanaan pembangunan desa hanya melihat kepentingan desa secara umum dan tidak melihat kepentingan masyarakat desa di tiap-tiap dusun dan kampung yang membutuhkan pembangunan dengan pemanfaatan sumber daya lokal.

Permasalahan pembangunan yang tidak melibatkan sumber daya lokal seperti masyarakat desa dan potensi sumber daya alam yang dimiliki menjadi salah satu permasalahan perencanaan

\footnotetext{
2 Presiden Republik Indonesia, Undang-Undang Nomor 6 Tabun 2014 Tentang Desa (Indonesia, 2014).
} 
pembangunan yang belum akomodatif. Pembangunan desa dalam pelaksanaannya memanfaatkan pihak ketiga atau investor dengan pemanfaatan teknologi tingkat tinggi yang tidak dapat dijangkau oleh masyarakat sehingga masyarakat desa hanya berperan menjadi penonton dan tidak dapat berpartisipasi secara aktif dalam proses pembangunan.

Penguatan kapasitas masyarakat desa terkait grand desain perencanaan pembangunan memiliki urgensi untuk meningkatkan efektifitas, akuntabilitas dan transparansi dalam pengelolaan pembangunan desa termasuk penggunaan sumber daya lokal. Hal tersebut sejalan dengan paradigma pembangunan yang memberikan daya pendekatan pembangunan partisipatif masyarakat sebagai basis pengambilan keputusan dalam upaya menggerakan perekonomian perdesaan, mendorong partisipasi masyarakat dalam bidang politik, memperkuat nilai-nilai sosial dan budaya lokal serta meningkatkan kesejahteraan masyarakat. Selain itu melalui sebuah proses perubahan sosial, ekonomi dan politik untuk memberdayakan dan memperkuat kemampuan masyarakat melalui proses belajar bersama yang partisipatif, agar terjadi perubahan perilaku pada diri semua stakeholders (individu, kelompok dan kelembagaan) yang terlibat dalam proses pembangunan demi terwujudnya kehidupan yang semakin berdaya, mandiri dan partisipatif yang semakin sejahtera secara berkelanjutan. ${ }^{3}$

Melalui grand design perencanaan pembangunan yang diinisiasi oleh masyarakat lokal maka diharapkan kebutuhan masyarakat terhadap sebuah proses pembangunan akan lebih terakomodir, hal tersebut didasarkan pada kondidi objektif bahwa yang paling tahu dan memahami apa dan bagaimana kebutuhan pembangunan adalah masyarakat itu sendiri. Di sisi lain, grand design perencanaan pembangunan yang dilakukan oleh masyarakat sebagai aktor utama pembangunan merupakan sebuah bentuk kemandirian dan partisipasi yang bertumpu pada pemberdayaan masyarakat.

Kegiatan pengabdian masyarakat ini bekerjasama dengan masyarakat di desa Cilangkap Kecamatan Wanasalam Kabupaten Lebak. Desa Cilangkap merupakan salah satu desa yang berada di wilayah Kecamatan Wanasalam Kabupaten Lebak dengan jarak 7 Km dari kecamatan dan jarak 70 $\mathrm{km}$ dari pusat kabupaten. Secara geografis berbatasan dengan:

a. Sebelah utara berbatasan dengan Desa Parungpanjang dan Desa Kertaraharja Kecamatan Banjarsari

\footnotetext{
${ }^{3}$ Mardikanto T and Soebiato P, Pemberdayaan Masyarakat Dalam Perspektif Kebijakan Publik (Bandung: Alfabeta, 2013$) .100$.
} 
b. Sebelah Selatan berbatasan dengan Desa Parungsari Kecamatan Wanasalam

c. Sebelah Barat berbatasan dengan Desa Karangpamidangan Kecamatan Wanasalam

d. Sebelah Timur berbatasan dengan Desa Senanghati Kecamatan Malingping

Desa Cilangkap memiliki luas wilayah $831,7 \mathrm{Ha}$, dengan pemanfaatan areal persawahan 44 Ha, peladangan 318,8 Ha, Pemukiman 53 Ha, Perkebunan $96 \mathrm{Ha}$, fasilitas umum desa 15,9 Ha dan Kehutanan 310 Ha. Dengan jumlah penduduk sebanyak 2.178 jiwa dan 577 Kepala Keluarga (KK) yang terdiri dari 1.148 laki-laki dan dan 1.030 perempuan dengan jumlah KK miskin sebanyak 566. Secara umum aksesibilitas menuju Desa Cilangkap relatif mudah karena terletak di antara jalan poros kecamatan dan jalan batas desa, jenis jalan alternatif poros kecamatan dan desa adalah tanah, pasir batu dan jalan aspal akan tetapi untuk menuju kantor desa relative sulit dijangkau oleh transportasi umum karena akses jalan transportasi adalah jalan batu (macadam) dan minimnya aspal hotmix sedangkan aksesbilitas kesulitan lainnya menuju Desa Cilangkap adalah karena letaknya yang jauh dari pusat kabupaten dan berada di daerah pinggiran selatan Kabupaten Lebak.

Data dan potensi ekonomi Desa Cilangkap sangat dipengaruhi oleh kondisi wilayah Desa yang sebagian besar dikelilingi oleh areal kehutanan dan perkebunan rakyat, adapun potensi Desa Cilangkap yang ditinjau baik dari sumber daya manusia maupun sumber daya alam sampai saat ini potensi tersebut belum benar-benar optimal diberdayakan.

\section{Permasalahan}

Berdasarkan analisis situasi melalui observasi, wawancara dan survey yang telah dilakukan terdapat berbagai permasalahan yang disepakati, diantaranya yaitu:

1. Musyawarah Perencanaan Pembangunan (Musrenbang) desa sebagai forum dialog warga dalam membahas permasalahan-permasalah pembangunan perdesaan belum memberikan ruang partisipasi terhadap warga dalam mengemukakan kebutuhannya dan dilakukan hanya sekedar menggugurkan kewajiban bagi aparat desa.

2. Makna Musyawarah Perencanaan Pembangunan (Musrenbang) Desa hanya menjadi forum perencanaan pembangunan perdesaan yang bersifat jangka pendek dimana warga desa diposisikan secara pasif hanya untuk mendengarkan program-program pembangunan yang akan dijalankan. 
3. Masih dominannya pengaruh kepala desa dalam mengambil keputusan-keputusan strategis dengan tidak melibatkan warga desa secara aktif sehingga menghambat aspirasi dan partisipasi warga dalam proses pembangunan.

4. Kebutuhan masyarakat untuk berpartisipasi dalam proses pembangunan menjadi terhambat karena pembangunan dilaksanakan oleh pihak ketiga/investor dengan pemanfaatan teknologi tingkat tinggi yang tidak dapat dijangkau oleh masyarakat desa.

\section{Metode Pelaksanaan Kegiatan}

Pemberdayaan masyarakat dan Penguatan Kapasitas Masyarakat dilaksanakan melalui: (1) memposisikan masyarakat sebagai penentu/pengambil kebijakan dan pelaku utama pembangunan, (2) mengutamakan nilai-nilai universal dan budaya serta kearifan lokal dalam pelaksanaan tahapan kegiatan, sesuai dengan karakteristik sosial, budaya dan geografis. Sedangkan Metode yang digunakan adalah gabungan dari dua metode pemberdayaan masyarakat yaitu Participatory Rapid Appraisal (PRA) atau penilaian desa secara partisipatif dan Participatory Learning and Action (PLA) atau proses belajar/praktik secara partisipatif.

Metode Participatory Rapid Appraisal (PRA) atau penilaian desa secara partisipatif dilakukan melalui berbagai kegiatan sebagai berikut:

1) Pemetaan wilayah dan kegiatan yang terkait dengan topik penilaian keadaan;

2) Analisis keadaan yang berupa:

- Keadaan masa lalu, sekarang dan kecenderungan di masa depan;

- Identifikasi tentang perubahan-perubahan yang terjadi dan alasan-alasan atau penyebabnya;

- Identifikasi (akar) masalah dan alternatif-alternatif pemecahan masalah;

- Kekuatan, kelemahan, peluang dan ancaman atau analisis strenght, weakness, opportunity and threat (SWOT) terhadap semua alternatif pemecahan masalah.

3) Pemilihan alternatif pemecahan masalah yang paling layak atau dapat dihandalkan (dapat dilaksanakan, efisien dan diterima oleh sistem sosialnya)

4) Rincian tentang stakeholders dan peran yang diharapkan dari para pihak, serta jumlah dan sumber-sumber pembiayaan yang dapat diharapkan untuk melaksanakan program kegiatan yang akan diusulkan/direkomendasikan.

Volume 1, Number 2, November 2017| 223

Pemberdayaan Masyarakat melalui Inovasi Perencanaan Pembangunan berbasis 4R (Rembug, Rencana, Realisasi dan Rawat) di Desa Cilangkap Kecamatan Wanasalam sebagai Pilar Utam a Kebijakan Partisipatif dan Gotong Royong 
Selanjutnya metode pengabdian masyarakat berkonsep Participatory Learning and Action (PLA) dilakukan dengan menekankan pada kegiatan ceramah, diskusi, curah pendapat yang dilakukan secara interaktif dengan masyarakat dan dilanjutkan dengan aksi atau kegiatan riil yang relevan dengan materi pemberdayaan masyarakat. PLA merupakan bentuk baru dari metode pemberdayaan masyarakat yang sebelumnya lebih dikenal dengan 'Learning by Doing' atau belajar sambil bekerja. Participatory Learning Action merupakan proses belajar secara berkelompok yang dilakukan secara interaktif dalam suatu proses kerja. ${ }^{6}$

Berdasarkan kedua metode pemberdayaan masyarakat tersebut, pelaksanaan kegiatan pengabdian ini akan dilaksanakan melalui tiga tahap yaitu tahap awal, tahap inti dan tahap akhir. Secara umum tahapan kegiatan pengabdian ini dapat dilihat pada gambar 1. Berikut penjelasan pada masing-masing tahap kegiatan.

1) Tahap awal. Kegiatan pada tahap ini meliputi (a) observasi partisipatif dan survey. Dilakukan sebagai analisis awal untuk mendapat informasi mendalam dan menyeluruh mengenai permasalahan di desa dan mencari solusi yang dibutuhkan dan tepat sasaran; (b) pemetaan wilayah desa, (c) kelengkapan administrasi dilakukan sebagai prosedur formal untuk melegalkan kegiatan pengabdian; dan (c) merancang kegiatan inti berupa analisis keadaan dan pemilihan alternatif pemecahan masalah dan pembagian peran para pihak yang sesuai dengan kebutuhan mitra dan sebagai solusi dari permasalahan yang dihadapi.

2) Tahap inti. Dalam tahap kedua ini, fokus kegiatan pengabdian dilakukan yaitu melakukan diskusi, pendampingan dan bimbingan melalui serangkaian kegiatan. Ada lima kegiatan yang akan diikuti oleh mitra, yaitu:

a. Sosialisasi kebutuhan masyarakat dan identifikasi permasalahan melalui kegiatan rembug warga

b. Melakukan analisis keadaan yang berupa keadaan masa lalu, sekarang dan kecenderungan di masa depan;

\footnotetext{
${ }^{4}$ K. Phuyal, "Participatory Learning and Action [PLA]: A Brief Introduction."

${ }^{5}$ Aprillia Theresia and et all, Pembangunan Berbasis Masyarakat (Bandung: Alfabeta, 2104).

${ }^{6}$ K. Appel, K., Bu ckingham, E Jodoin and D. Roth, Participatory Learning and Action Toolkit: For Application in BSR's Global Programs (Paris: BSR, 2012).
}

Volume 1, Number 2, November $2017 \mid 224$

Pemberdayaan Masyarakat melalui Inovasi Perencanaan Pembangunan berbasis 4R (Rembug, Rencana, Realisasi dan Rawat) di Desa Cilangkap Kecamatan Wanasalam sebagai Pilar Utam a Kebijakan Partisipatif dan Gotong Royong 
c. Melakukan identifikasi tentang perubahan-perubahan yang terjadi dan alasan-alasan atau penyebabnya;

d. Menyusun alternatif pemecahan masalah

e. Melakukan analisis kekuatan, kelemahan, peluang dan ancaman atau analisis strenght, weakness, opportunity and threat (SWOT) terhadap semua alternatif pemecahan masalah.

f. Merumuskan pemilihan alternatif pemecahan masalah yang paling layak atau dapat dihandalkan

g. Menyusun pembagian peran para stakeholders dan sumber-sumber pembiayaan yang dapat diharapkan untuk melaksanakan program kegiatan yang akan diusulkan/direkomendasikan.

3) Tahap akhir. Ada tiga kegiatan dalam tahap ini yaitu (a) evaluasi kegiatan yang akan dilakukan per kegiatan dan secara menyeluruh; (b) sosialisasi grand design perencanan pembangunan

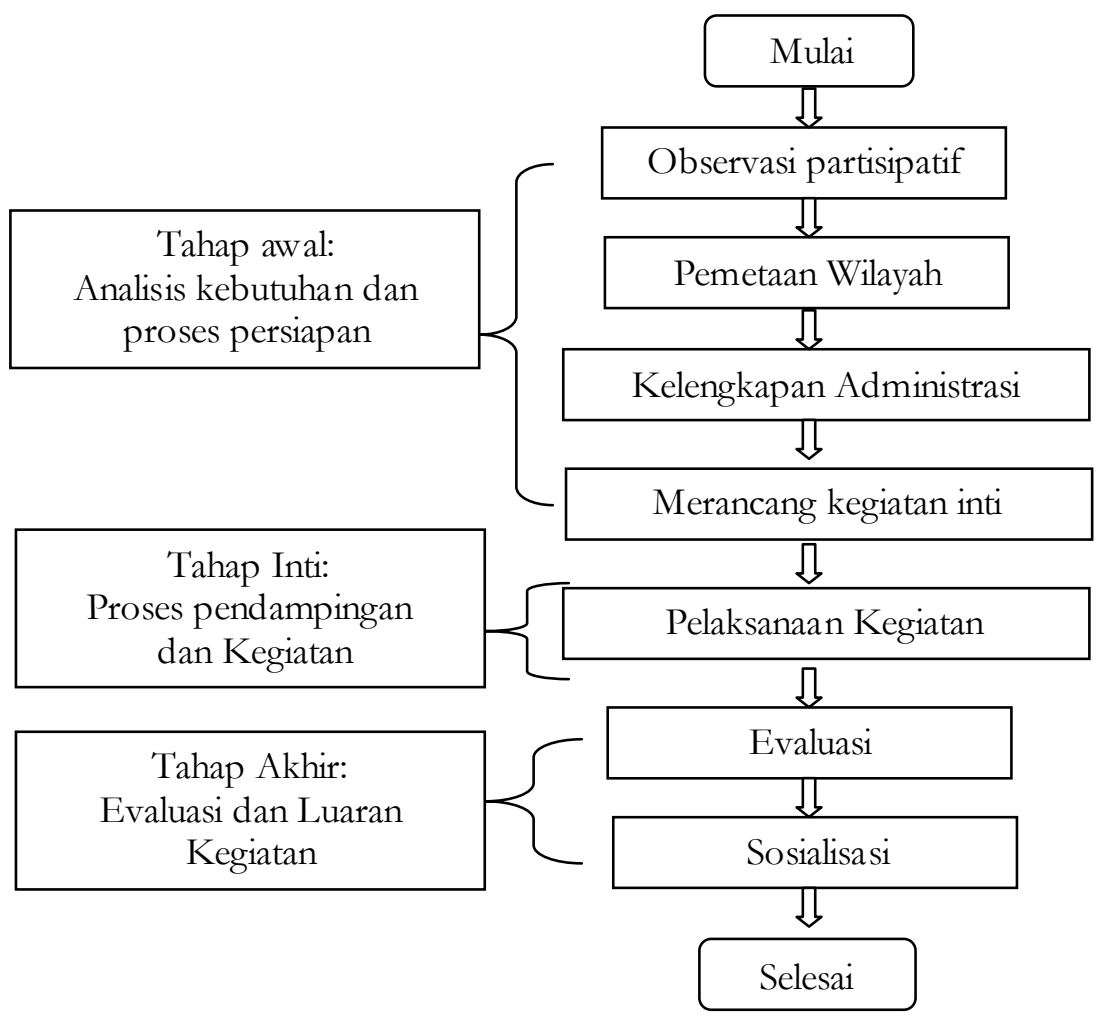

Volume 1, Number 2, November 2017| 225

Pemberdayaan Masyarakat melalui Inovasi Perencanaan Pembangunan berbasis 4R (Rembug, Rencana, Realisasi dan Rawat) di Desa Cilangkap Kecamatan Wanasalam sebagai Pilar Utam a Kebijakan Partisipatif dan Gotong Royong 


\section{Hasil dan Diskusi}

Kegiatan pendampingan ini dilakukan selama 6 (enam) bulan yaitu minggu ketiga bulan September 2016 s/d minggu keempat bulan Maret 2017.

\section{Tahap Awal (Sosialisasi Desa)}

Sosialisasi desa dilakukan sebanyak 3 (tiga) kali dengan waktu dan tema kegiatan sebagai berikut:

\section{Sosialisasi desa tahap satu}

Pada tahap ini, proses pendampingan dilakukan dengan melakukan ceramah dan diskusi dengan warga desa, materi yang disampaikan adalah terkait dengan tujuan dan manfaat perencanaan pembangunan, pentingnya partisipasi masyarakat dalam proses perencanaan pembangunan, penguatan kapasitas masyarakat dalam perencanaan pembangunan dan pentingnya perencanaan pembangunan yang diinisiasi oleh masyarakat sebagai salah satu pilar kebijakan partisipatif masyarakat dan gotong royong. Peserta dalam kegiatan sosialisasi desa tahap satu ini berjumlah 43 orang yang berasal dari 7 (tujuh) dusun yang terdiri dari ketua dusun dan tokoh masyarakat.
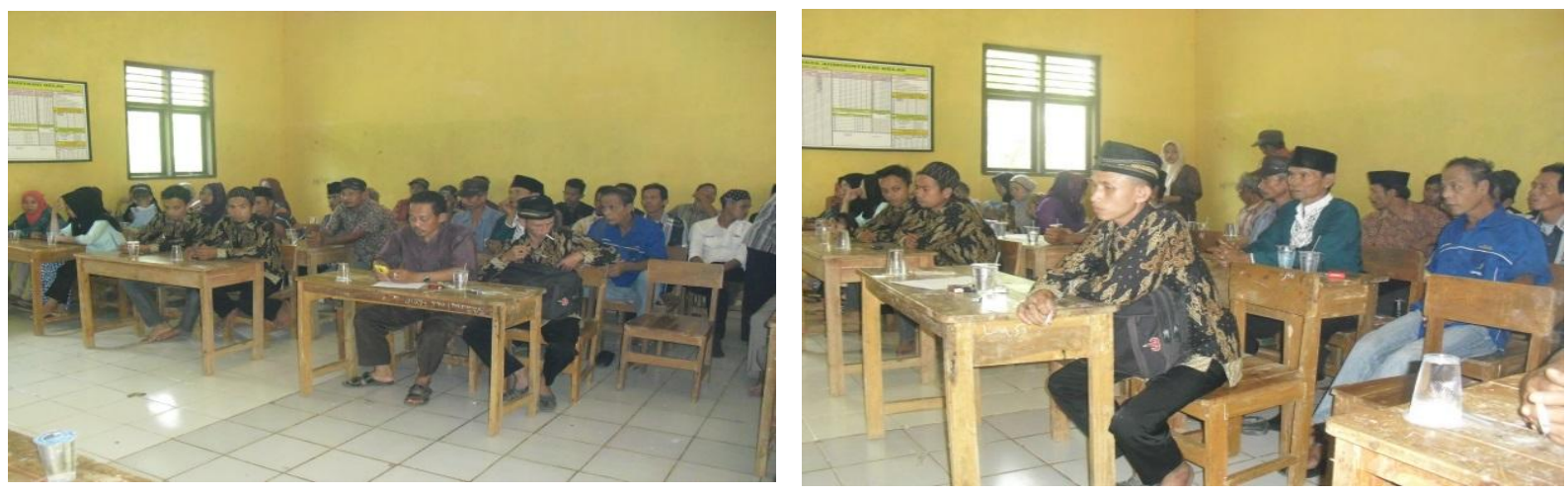

Gambar 2. Sosialisasi Desa Tahap 1

\section{Sosialisasi desa tahap dua}

Pada tahap awal ini disusun rancangan kegiatan inti berupa analisis keadaan desa, identifikasi kebutuhan pembangunan, pemilihan alternatif pemecahan masalah dan sosialisasi konsep perencanaan pembangunan 4 (empat) R yaitu Rembug, Rencana, Realisasi dan Rawat. Peserta dalam kegiatan sosialisasi desa tahap satu ini berjumlah 27 orang yang berasal dari 7 (tujuh) dusun yang terdiri dari ketua dusun dan tokoh masyarakat.

\section{Sosialisasi desa tahap tiga}

Pada tahap ketiga ini, dilakukan pembagian peran para pihak yang sesuai dengan kebutuhan mitra dan

Volume 1, Number 2, November 2017 | 226 Pemberday aan Masyarakat melalui Inovasi Perencanaan Pembangunan berbasis 4R (Rembug, Rencana, Realisasi dan Rawat) di Desa Cilangkap Kecamatan Wanas alam sebagai Pilar Utama Kebijakan Partisipatif dan Go tong Royong Ahmad Sururi, Rahmi Mulyasih 


\section{ENGAGEMENT}

JurnalPengabdianKepada Masyarakat

ISSN : 2579-8375 (Print)

ISSN: 2579-8391 (Online)
This work is licensed under a Creative Commons

Attribution-ShareAlike 4.0 International License.

sebagai solusi dari permasalahan yang dihadapi. Output dari kegiatan sosialisasi tahap ketiga adalah terbentuknya susunan Organisasi Perencana Masyarakat Desa (OPMD) yang berasal dari unsur pemerintahan desa, kepala Dusun, tokoh pemuda dan tokoh masyarakat.
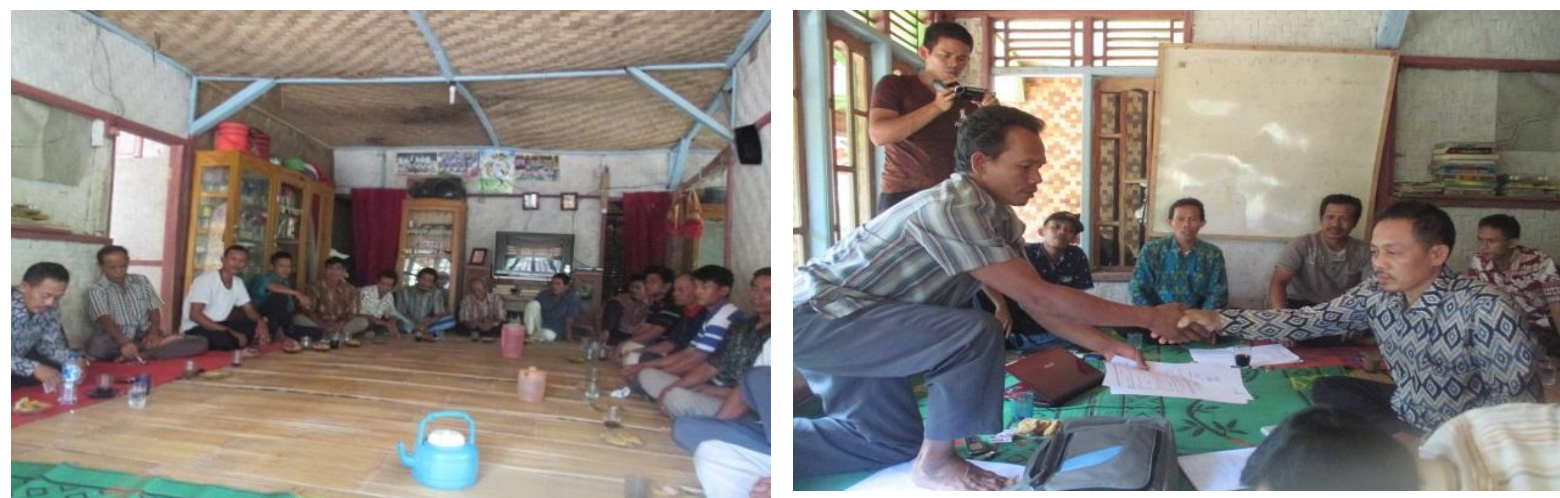

Gambar 3. Sosialisasi Desa Tahap 3 dan Pemiliban Ketua OPPD

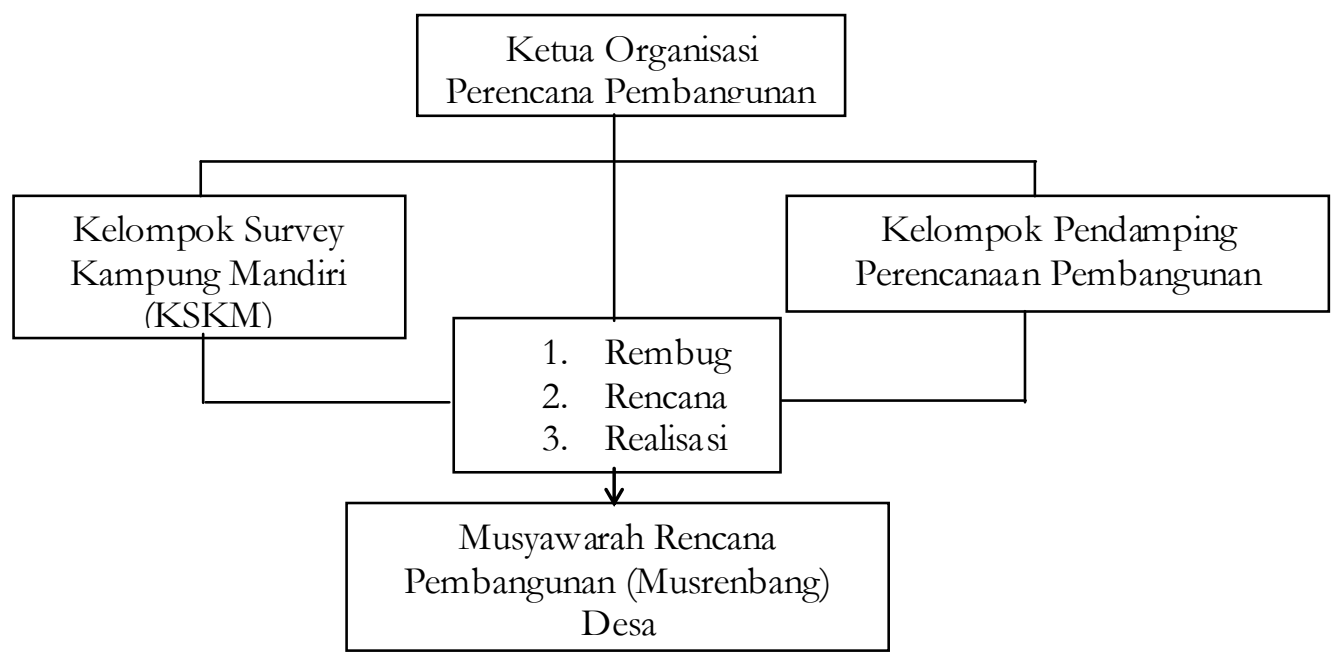

Gambar4. Bagan Struktur Organisasi Perencana Pembangunan Desa

a) Organisasi Perencana Pembangunan Desa (OPPD) adalah warga masyarakat desa yang dipilih secara langsung oleh masyarakat desa berdasarkan kemampuan yang dimiliki. Adapun persyaratan yang harus dimiliki adalah memiliki kemampuan baca tulis dan dapat diterima oleh semua pihak baik dari unsur pemerintahan desa maupun lapisan masyarakat setempat.

Peran OPPD adalah sebagai penanggung jawab operasional perencanaan pembangunan desa

Volume 1, Number 2, November 2017| 227 Pemberday aan Masyarakat melalui Inovasi Perencanaan Pembangunan berbasis 4R (Rembug, Rencana, Realisasi dan Rawat) di Desa Cilangkap Kecamatan Wanas alam sebagai Pilar Utama Kebijakan Partisipatif dan Go tong Royong Ahmad Sururi, Rahmi Mulyasih 
ENGAGEMENT

JurnalPengabdiankepadaMasyarakat

ISSN : 2579-8375 (Print)

ISSN: 2579-8391 (Online)
This work is licensed under a Creative Commons

Attribution-ShareAlike 4.0 International License.

b) Kelompok Survey Kampung Mandiri (KSKM) adalah kelompok yang terdiri dari berbagai unsur masyarakat seperti tokoh pemuda dan perwakilan masyarakat dari tiap RT dan RW. KSMD harus bersifat representatif karena bertugas melakukan survey mandiri kesetiap kampung/dusun untuk melakukan pemetaan dan identifikasi kebutuhan desa baik dari segi pembangunan fisik maupun non fisik.

c) Kelompok Pendamping Perencanaan Pembangunan Desa (KP3D) adalah tim pendamping yang akan memberikan saran dan masukan terkait dengan perencanaan pembangunan. Anggota KP3D terdiri dari aparat pemerintahan desa, tokoh masyarakat dan ketua RT/RW dari masyarakat.

Fokus kegiatan dari ketiga organisasi masyarakat lokal yang telah dibentuk adalah menyusun perencanaan pembangunan dengan berbasis pada konsep 4R yaitu Rembug, Rencana, Realisasi dan Rawat sebagai langkah-langkah inovasi kebijakan perencanaan pembangunan desa. Kemudian hasil dari formulasi kebijakan perencanaan pembangunan disampaikan pada kegiatan Musyawarah Rencana Pembangunan (Musrenbang) desa yang merupakan mekanisme formil perencanaan pembangunan desa.

\section{Tahap Kedua (Survey Kampung Mandiri)}

Setelah organisasi lokal terbentuk, kemudian dilakukan survey kampung mandiri yang dilakukan oleh KSKM yang telah terbentuk. Tugas dan tanggung kawab KSKM adalah melakukan survey mandiri kesetiap kampung/dusun untuk melakukan pemetaan dan identifikasi kebutuhan pembangunan desa baik dari segi pembangunan fisik maupun non fisik.
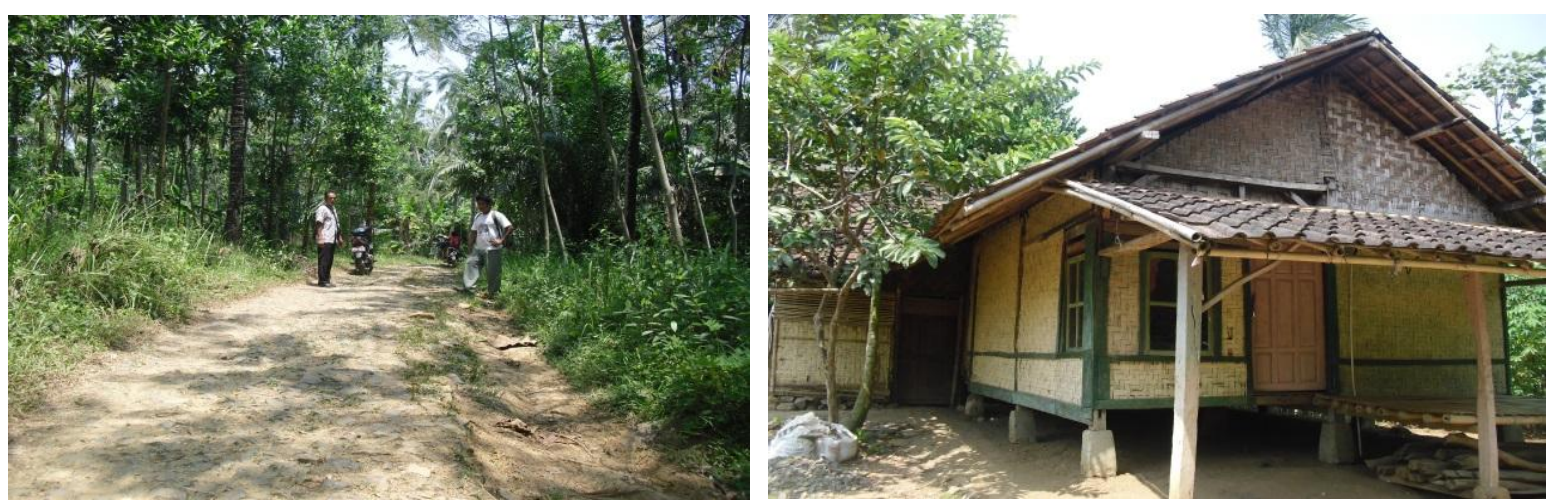

Gambar5. Kondisi Rumah Warga Desa Cilangkap

Volume 1, Number 2, November 2017| 228 Pemberday aan Masyarakat melalui Inovasi Perencanaan Pembangunan berbasis 4R (Rembug, Rencana, Realisasi dan Rawat) di Desa Cilangkap Kecamatan Wanas alam sebagai Pilar Utama Kebijakan Partisipatif dan Go tong Royong Ahmad Sururi, Rahmi Mulyasih 
ENGAGEMENT

JurnalPengabdianरepada Masyarakat

ISSN : 2579-8375 (Print)

ISSN: 2579-8391 (Online)
This work is licensed under a Creative Commons Attribution-ShareAlike 4.0 International License.

Hasil suvey Kampung Mandiri dapat diuraikan sebagai berikut:

Tabel 1. Hasil Survey Kampung Sukasari 1

\begin{tabular}{ccll}
\hline No & $\begin{array}{c}\text { Jumlah } \\
\text { KK }\end{array}$ & \multicolumn{1}{c}{ Prioritas Permasalahan } & \multicolumn{1}{c}{ Kebutuhan } \\
\hline $\mathbf{1}$ & 62 & $\begin{array}{l}\text { Sarana infrastruktur jalan kampung yang masih berupa tanah } \\
\text { sehingga menghambat akses transportasi }\end{array}$ & $\begin{array}{l}\text { Pembangunan } \\
\text { telford/ Makadam }\end{array}$ \\
\cline { 4 - 5 } & & $\begin{array}{l}\text { Jembatan penghubung antar dusun terbuat dari kayu dan } \\
\text { sudah dalam kondisi rusak }\end{array}$ & Pembangunan Jembatan \\
\hline $\mathbf{2}$ & & & \\
\hline
\end{tabular}

Tabel 2. Hasil Survey Kampung Sukasari 2

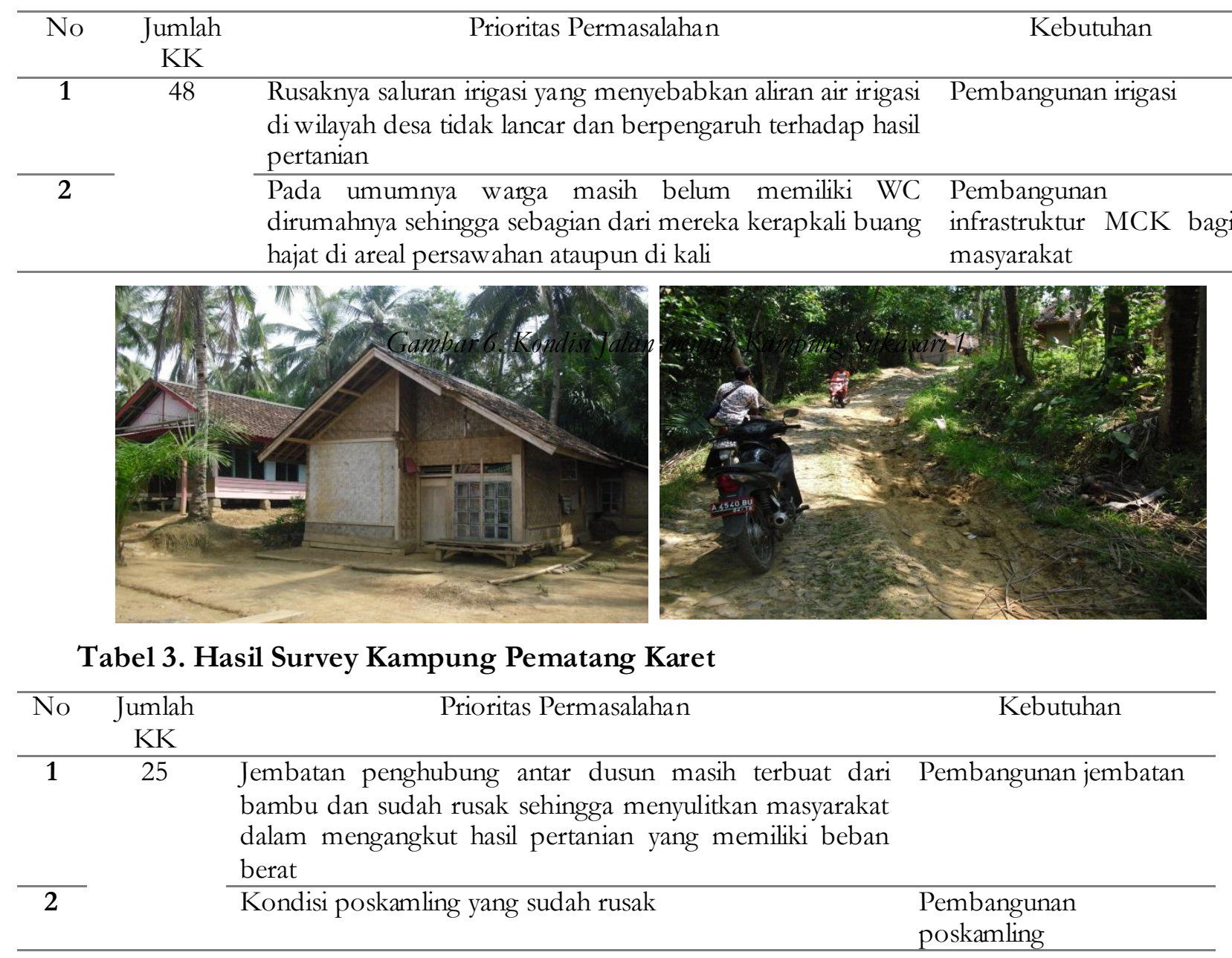

Volume 1, Number 2, November 2017 | 229

Pemberday aan Masyarakat melalui Inovasi Perencanaan Pembangunan berbasis 4R (Rembug, Rencana, Realisasi dan Rawat) di Desa Cilangkap Kecamatan Wanas alam sebagai Pilar Utama Kebijakan Partisipatif dan Gotong Royong

Ahmad Sururi, Rahmi Mulyasih 
Tabel 4. Hasil Survey Kampung Lebak Jaha

\begin{tabular}{|c|c|c|c|}
\hline No & $\begin{array}{l}\text { Jumlah } \\
\text { KK }\end{array}$ & Prioritas Permasalahan & Kebutuhan \\
\hline 1 & 73 & $\begin{array}{l}\text { Untuk mencuci dan mandi, sebagian warga masih } \\
\text { menggunakan air kali }\end{array}$ & Pembangunan MCK \\
\hline 2 & & $\begin{array}{l}\text { Belum adanya bangunan TK dan SD dan bangunan sarana } \\
\text { lainnya }\end{array}$ & $\begin{array}{l}\text { Pembangunan sarana } \\
\text { lembaga pendidikan TK } \\
\text { dan SD }\end{array}$ \\
\hline 3 & & Belum adanya instalasi air minum bersih bagi warga & $\begin{array}{l}\text { Kebutuhan } \\
\text { pembangunan } \\
\text { air minum }\end{array}$ \\
\hline
\end{tabular}

Tabel 3. Hasil Survey Kampung Pematang Karet

\begin{tabular}{|c|c|c|c|}
\hline No & $\begin{array}{c}\text { Jumlah } \\
\text { KK }\end{array}$ & Prioritas Permasalahan & Kebutuhan \\
\hline 1 & 25 & $\begin{array}{l}\text { Jembatan penghubung antar dusun masih terbuat dari } \\
\text { bambu dan sudah rusak sehingga menyulitkan masyarakat } \\
\text { dalam mengangkut hasil pertanian yang memiliki beban } \\
\text { berat }\end{array}$ & Pembangunan jembatan \\
\hline 2 & & Kondisi poskamling yang sudah rusak & $\begin{array}{l}\text { Pembangunan } \\
\text { poskamling }\end{array}$ \\
\hline
\end{tabular}

Tabel 4. Hasil Survey Kampung Lebak Jaha

\begin{tabular}{|c|c|c|c|}
\hline No & $\begin{array}{l}\text { Jumlah } \\
\text { KK }\end{array}$ & Prioritas Permasalahan & Kebutuhan \\
\hline 1 & 73 & $\begin{array}{l}\text { Untuk mencuci dan mandi, sebagian warga masih } \\
\text { menggunakan air kali }\end{array}$ & Pembangunan MCK \\
\hline 2 & & $\begin{array}{l}\text { Belum adanya bangunan TK dan SD dan bangunan sarana } \\
\text { lainnya }\end{array}$ & $\begin{array}{l}\text { Pembangunan sarana } \\
\text { lembaga pendidikan TK } \\
\text { dan SD }\end{array}$ \\
\hline 3 & & Belum adanya instalasi air minum bersih bagi warga & $\begin{array}{l}\text { Kebutuhan } \\
\text { pembangunan instala } \\
\text { air minum }\end{array}$ \\
\hline
\end{tabular}

Tabel 5. Hasil Survey Kampung Warung Jogjog

\begin{tabular}{|c|c|c|c|}
\hline & $\begin{array}{l}\text { Jumlah } \\
\mathrm{KK}\end{array}$ & Permasalahan dan Potensi & $\begin{array}{l}\text { Kebutuhan dan usulan } \\
\text { kegiatan }\end{array}$ \\
\hline 1 & 92 & $\begin{array}{l}\text { Sebagai pusat desa, bangunan kantor desa sudah tidak } \\
\text { layak }\end{array}$ & $\begin{array}{l}\text { Pembangunan } \\
\text { kantor desa }\end{array}$ \\
\hline 2 & & $\begin{array}{l}\text { Belum adanya sarana penerangan jalan umum disepanjang } \\
\text { jalan desa }\end{array}$ & $\begin{array}{l}\text { Pembangunan } \\
\text { PJU }\end{array}$ \\
\hline 3 & & Sarana pertanian masih manual & $\begin{array}{l}\text { Penyediaan sarana dan } \\
\text { prasarana pertanian }\end{array}$ \\
\hline
\end{tabular}

Volume 1, Number 2, November 2017 | 230 Pemberday aan Masyarakat melalui Inovasi Perencanaan Pembangunan berbasis 4R (Rembug, Rencana, Realisasi dan Rawat) di Desa Cilangkap Kecamatan Wanas alam sebagai Pilar Utama Kebijakan Partisipatif dan Go tong Royong

Ahmad Sururi, Rahmi Mulyasih 


\section{ENGAGEMENT}

JurnalPengabdianKepada Masyarakat

ISSN : 2579-8375 (Print)

ISSN: 2579-8391 (Online)
This work is licensed under a Creative Commons Attribution-ShareAlike 4.0 International License.
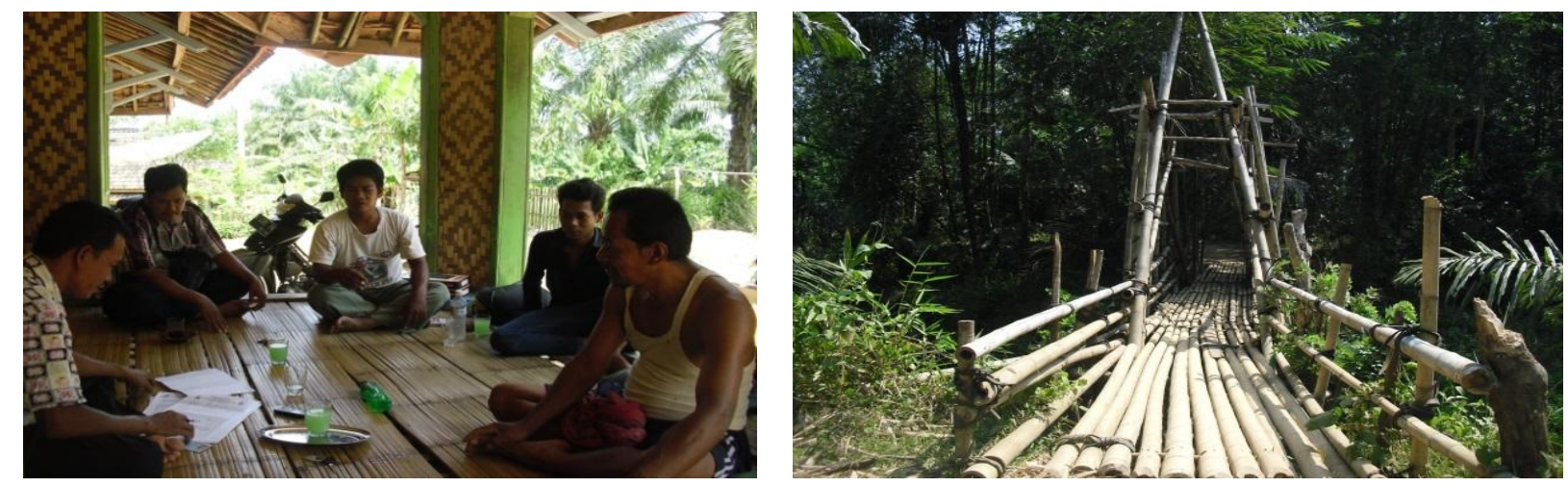

Gambar 7. Diskusi dengan warga Kampung Cikaredok. (kiri) dan Kondisi Jembatan bambu Kampung Pematang Karet (kanan)

Tabel 6. Hasil Survey Kampung Cikaredok

\begin{tabular}{ccll}
\hline No & $\begin{array}{c}\text { Jumlah } \\
\text { KK }\end{array}$ & \multicolumn{1}{c}{ Prioritas Permasalahan } & \multicolumn{1}{c}{ Kebutuhan } \\
\hline $\mathbf{1}$ & 25 & Bangunan posyandu tidak ada & Pembangunan Posyandu \\
\cline { 4 - 4 } $\mathbf{2}$ & & Saluran induk pembuangan limbah & Pembangunan drainase \\
\hline $\mathbf{3}$ & & Sebagian warga belum memiliki MCK & $\begin{array}{l}\text { Pembangunan MCK } \\
\text { untuk warga }\end{array}$ \\
\hline
\end{tabular}

Tabel 7. Hasil Survey Kampung Ciparaha

\begin{tabular}{cclll}
\hline No & $\begin{array}{c}\text { Jumlah } \\
\text { KK }\end{array}$ & \multicolumn{1}{c}{ Prioritas Permasalahan } & \multicolumn{2}{c}{ Kebutuhan } \\
\hline $\mathbf{1}$ & 48 & Jalan kampung masih berupa tanah & $\begin{array}{l}\text { Pembangunan } \\
\text { Paving Block }\end{array}$ & jalan \\
\cline { 4 - 5 } & & $\begin{array}{l}\text { Belum adanya bangunan SD sehingga menyulitkan anak- } \\
\text { anak usia SD bersekolah dan harus menempuh jarak yang } \\
\text { cukup jauh }\end{array}$ & $\begin{array}{l}\text { Pembangunan } \\
\text { pendidikan SD }\end{array}$ & sarana \\
& & & \\
\hline
\end{tabular}

Tabe1 8. Hasil Survey Kampung Cisujen

\begin{tabular}{ccclc}
\hline No & $\begin{array}{c}\text { Jumlah } \\
\text { KK }\end{array}$ & \multicolumn{1}{c}{ Prioritas Permasalahan } & \multicolumn{2}{c}{ Kebutuhan } \\
\hline $\mathbf{1}$ & 36 & Sebagian besar bangunan rumah warga sangat tidak layak & $\begin{array}{l}\text { Pembangunan } \\
\text { warga }\end{array}$ & rumah \\
\hline $\mathbf{2}$ & & $\begin{array}{l}\text { Sarana jembatan sebagai penghubung antar dusun masih } \\
\text { terbuat dari bambu }\end{array}$ & \begin{tabular}{l} 
Pembangunan Jembatan \\
\hline
\end{tabular} \\
\hline
\end{tabular}

Volume 1, Number 2, November 2017 | 231

Pemberday aan Masyarakat melalui Inovasi Perencanaan Pembangunan berbasis 4R (Rembug, Rencana, Realisasi dan Rawat) di Desa Cilangkap Kecamatan Wanas alam sebagai Pilar Utama Kebijakan Partisipatif dan Gotong Royong

Ahmad Sururi, Rahmi Mulyasih 
Tabe1 9. Hasil Survey Kampung Dongdong

\begin{tabular}{|c|c|c|c|}
\hline No & $\begin{array}{l}\text { Jumlah } \\
\text { KK }\end{array}$ & Prioritas Permasalahan & Kebutuhan \\
\hline 1 & 82 & $\begin{array}{l}\text { Sarana jalan berupa tanah sehingga menyulitkan akses } \\
\text { transportasi warga }\end{array}$ & Pembangunan Jalan \\
\hline 2 & & Sebagian rumah warga belum teraliri listrik & $\begin{array}{l}\text { Pembangunan gardu } \\
\text { listrik yang dialirkan ke } \\
\text { rumah-rumah warga }\end{array}$ \\
\hline
\end{tabular}
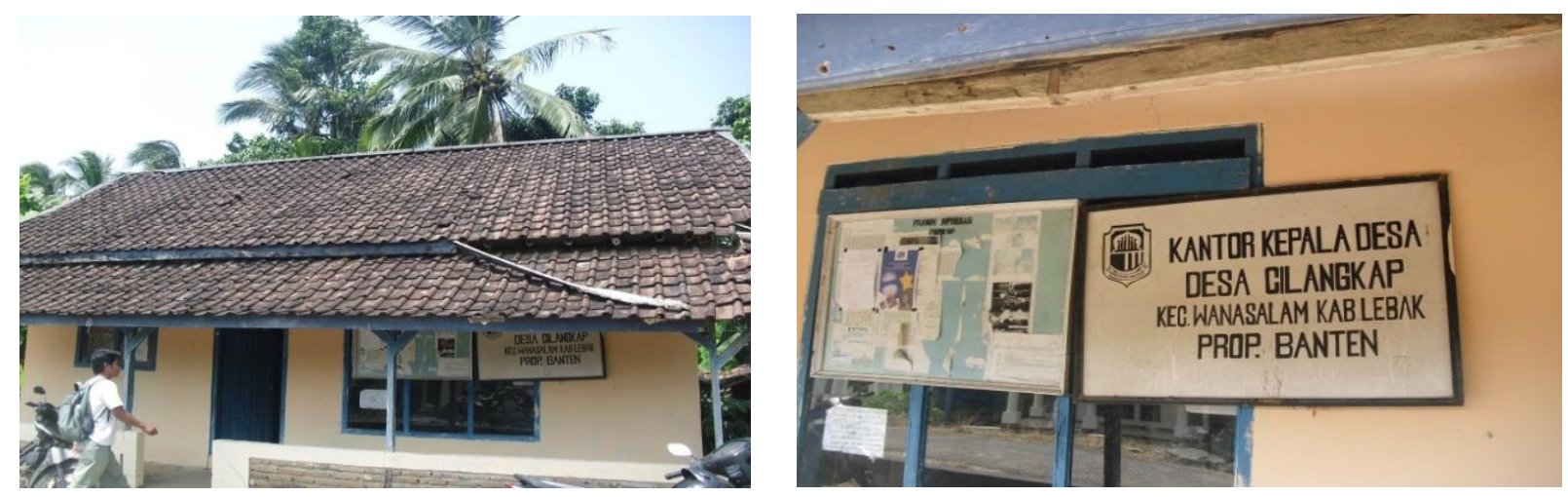

Gambar 9. Kantor Desa Cilangkap Kecamatan Wanasalam

Tabel 10. Hasil Survey Kampung Sawah

\begin{tabular}{cccc}
\hline No & $\begin{array}{c}\text { Jumlah } \\
\text { KK }\end{array}$ & \multicolumn{1}{c}{ Prioritas Permasalahan } & Kebutuhan \\
\hline $\mathbf{1}$ & 67 & Penggunaan alat pertanian yang masih manual & $\begin{array}{c}\text { Penyediaan sarana } \\
\text { pertanian }\end{array}$ \\
\cline { 4 - 5 } & & $\begin{array}{l}\text { Belum adanya sarana drainase dalam mengalirkan air ke } \\
\text { sungai-sungai }\end{array}$ & Pembangunan drainase \\
& & $\begin{array}{l}\text { Akses jalan penghubung tanah dan menyulitkan warga } \\
\text { dalam kondisi hujan }\end{array}$ & \\
\hline
\end{tabular}

Secara umum kondisi infrastruktur desa Cilangkap yang terdiri dari 10 (Sepuluh) kampung masih memprihatinkan baik dari akses dan kondisi jalan kampung, bangunan jembatan penghubung maupun kondisi rumah warga yang masih dalam kondisi kurang layak. Sedangkan dari hasil survey didapatkan data bahwa sebagian besar masyarakat desa Cilangkap bermata pencahariaan sebagai buruh tani dan berada dalam taraf keluarga pra sejahtera.

Volume 1, Number 2, November 2017| 232 Pemberday aan Masyarakat melalui Inovasi Perencanaan Pembangunan berbasis 4R (Rembug, Rencana, Realisasi dan Rawat) di Desa Cilangkap Kecamatan Wanas alam sebagai Pilar Utama Kebijakan Partisipatif dan Gotong Royong Ahmad Sururi, Rahmi Mulyasih 


\section{Tahap Inti (Rembug, Rencana, Realisasi dan Rawat)}

Setelah proses hasil survey kampung mandiri diketahui, selanjutnya dilakukan penyusunan grand design perencanaan pembangunan dengan berpedoman kepada konsep 4 R yaitu Rembug, Rencana, Realisasi dan

Rawat.

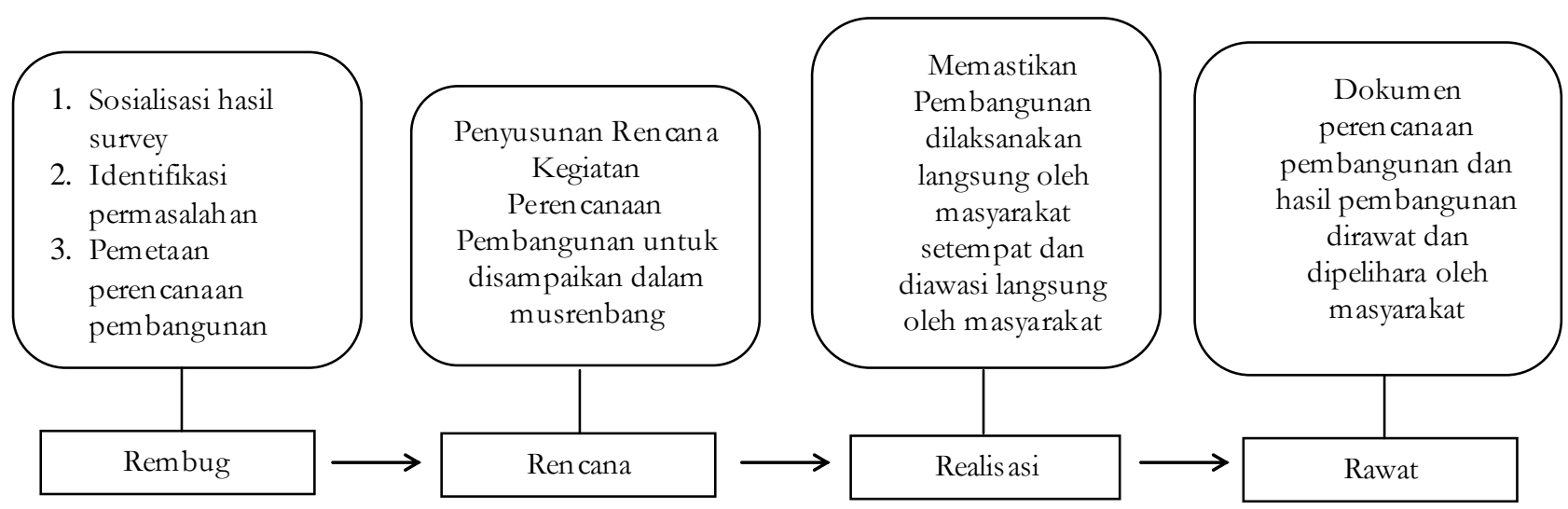

\section{Rembug}

Merupakan upaya yang dilakukan untuk menindaklanjuti hasil survey kampung mandiri. Kegiatan pendampingan yang dilakukan adalah:

a. Melakukan sosialisasi hasil survey melalui rembug warga.

b. Melakukan identifikasi dan pemetaan permasalahan. Hasil kesimpulan dari masing-masing rembug berdasarkan pemetaan masalah yang dilakukan di 10 (sepuluh) diuraikan dalam analisis prioritas kebutuhan usulan kegiatan perencanaan pembangunan

c. Analisis prioritas perencanaan pembangunan

Dari berbagai kebutuhan dan usulan kegiatan tiap-tiap dusun maka dapat disimpulkan pemetaan perencanaan pembangunan untuk setiap kampung adalah sebagai berikut:

Tabel 11. Analisis Prioritas Kebutuhan Perencanaan Pembangunan

\begin{tabular}{cll}
\hline No & \multicolumn{1}{c}{ Lokasi Kampung } & \multicolumn{1}{c}{$\begin{array}{c}\text { Analisis Prioritas Kebutuhan Usulan } \\
\text { Kegiatan Perencanaan Pembangunan }\end{array}$} \\
\hline $\mathbf{1}$ & Sukasari 1 & Pembangunan jalan telford \\
\hline $\mathbf{2}$ & Sukasari 2 & Pembangunan MCK bagi masyarakat yang belum memiliki \\
\hline $\mathbf{3}$ & Pematang Karet & Pembangunan Jembatan penghubung \\
\hline $\mathbf{4}$ & Lebak Jaha & $\begin{array}{l}\text { Pembangunan sarana pendidikan TK dan SD dan pembangunan sarana } \\
\text { air minum }\end{array}$ \\
\hline $\mathbf{5}$ & Warung Jogjog & Pembangunan sarana kantor desa \\
\hline
\end{tabular}

Volume 1, Number 2, November 2017| 233 Pemberday aan Masyarakat melalui Inovasi Perencanaan Pembangunan berbasis 4R (Rembug, Rencana, Realisasi dan Rawat) di Desa Cilangkap Kecamatan Wanas alam sebagai Pilar Utama Kebijakan Partisipatif dan Go tong Royong

Ahmad Sururi, Rahmi Mulyasih 


\begin{tabular}{rll}
\hline $\mathbf{6}$ & Cikaredok & Pembangunan drainase \\
\hline $\mathbf{7}$ & Ciparaha & Pembangunan Jalan paving block \\
\hline $\mathbf{8}$ & Cisujen & Pembangunan jembatan \\
\hline $\mathbf{9}$ & Dongdong & Pembangunan gardu listrik \\
\hline $\mathbf{1 0}$ & Kampung Sawah & Pembangunan jalan akses penghubung \\
\hline
\end{tabular}

Tahap selanjutnya adalah menginventarisir prioritas kebutuhan usulan kegiatan tersebut dalam sebuah analisis pemetaan perencanaan pembangunan sebagai berikut:

Tabel 12. Analisis Nilai dari kebutuhan dan Usulan Kegiatan

\begin{tabular}{|c|c|c|c|c|c|c|c|c|c|c|c|c|}
\hline \multirow[t]{2}{*}{ No } & \multirow[t]{2}{*}{ Aspek Penilaian } & Nilai & \multicolumn{10}{|c|}{ Nilai dari kebutuhan dan usulan kegiatan } \\
\hline & & & 1 & 2 & 3 & 4 & 5 & 6 & 7 & 8 & 9 & 10 \\
\hline \multirow[t]{3}{*}{1} & $\begin{array}{l}\text { Kegiatan pembangunan meningkatkan } \\
\text { kualitas dan akses terhadap pelayanan } \\
\text { dasar }\end{array}$ & & & & & & & & & & & \\
\hline & $\mathrm{A}=\mathrm{Iya}$ & $A=3$ & 3 & 2 & 1 & 3 & 3 & 1 & 1 & 3 & 3 & 3 \\
\hline & $\begin{array}{l}B=\text { Kurang } \\
C=\text { Tidak }\end{array}$ & $B=1$ & & & & & & & & & & \\
\hline \multirow[t]{4}{*}{2} & $\begin{array}{l}\text { Kegiatan pembangunan mendukung } \\
\text { peningkatan ekonomi masyarakat secara } \\
\text { produktif }\end{array}$ & & & & & & & & & & & \\
\hline & $\mathrm{A}=$ Sangat mendukung & $A=3$ & 2 & 1 & 2 & 3 & 2 & 1 & 2 & 2 & 2 & 2 \\
\hline & $\mathrm{B}=$ Kurang Mendukung & $B=2$ & & & & & & & & & & \\
\hline & $\mathrm{C}=$ Tidak mendukung & $C=1$ & & & & & & & & & & \\
\hline
\end{tabular}

3 Kegiatan pembangunan melibatkan masyarakat setempat secara langsung

\begin{tabular}{llllllllllll}
\hline $\mathrm{A}=$ Melibatkan & $\mathrm{A}=2$ & 2 & 2 & 2 & 2 & 2 & 2 & 2 & 2 & 2 & 2 \\
$\mathrm{~B}=$ Tidak Melibatkan & $\mathrm{B}=1$ & & & & & & & & & & \\
\hline
\end{tabular}

4 Manfaat pembangunan dirasakan secara langsung oleh masyarakat desa setempat

\begin{tabular}{llllllllllll}
$\mathrm{A}=$ Dirasakan & $\mathrm{A}=2$ & 1 & 2 & 2 & 2 & 2 & 2 & 2 & 2 & 2 & 2 \\
$\mathrm{~B}=$ Kurang dirasakan & $\mathrm{B}=1$ & & & & & & & & & & \\
\hline
\end{tabular}

5 Lahan yang akan digunakan merupakan milik umum/desa

\begin{tabular}{llllllllllll}
\hline $\mathrm{A}=$ Milik Desa & $\mathrm{A}=2$ & 2 & 2 & 2 & 2 & 2 & 2 & 2 & 2 & 2 & 2 \\
$\mathrm{~B}=$ Bukan Milik Desa & $\mathrm{B}=1$ & & & & & & & & & &
\end{tabular}

6 Besarnya biaya pembangunan dapat dijangkau oleh anggaran desa

\begin{tabular}{llllllllllll}
$\mathrm{A}=$ Dapat dijangkau & $\mathrm{A}=2$ & 2 & 2 & 1 & 2 & 2 & 1 & 2 & 2 & 2 & 2 \\
$\mathrm{~B}=$ Tidak dapat dijangkau & $\mathrm{B}=1$ & & & & & & & & & & \\
\hline
\end{tabular}

7 Pembangunan yang dilaksanakan menggunakan teknologi sederhana berdasarkan kemampuan teknis dan sumber daya lokal yang tersedia

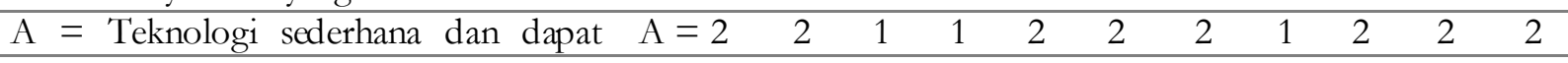

Volume 1, Number 2, November 2017| 234 Pemberday aan Masyarakat melalui Inovasi Perencanaan Pembangunan berbasis 4R (Rembug, Rencana, Realisasi dan Rawat) di Desa Cilangkap Kecamatan Wanas alam sebagai Pilar Utama Kebijakan Partisipatif dan Go tong Royong 


\begin{tabular}{|c|c|c|c|c|c|c|c|c|c|c|c|c|}
\hline & $\begin{array}{l}\text { diterapkan } \\
\mathrm{B}=\text { Teknologi tinggi dan tidak dapat } \\
\text { dterapkan }\end{array}$ & $\mathrm{B}=1$ & & & & & & & & & & \\
\hline \multirow[t]{5}{*}{8} & Waktu pelaksanaan pembangunan & & & & & & & & & & & \\
\hline & $\mathrm{A}=<3$ bulan & $A=2$ & 1 & 2 & 1 & 2 & 1 & 1 & 1 & 2 & 2 & 2 \\
\hline & $\mathrm{B}=>3$ bulan & $B=1$ & & & & & & & & & & \\
\hline & Total Nilai & & 15 & 14 & 12 & 18 & 16 & 12 & 14 & 18 & 18 & 17 \\
\hline & Peringkat & & 4 & 5 & 8 & 1 & 3 & 7 & 6 & 1 & 1 & 2 \\
\hline
\end{tabular}

Berdasarkan tabel 12 tersebut dapat dijelaskan bahwa nilai kebutuhan dan usulan kegiatan yang mendapatkan peringkat pertama dan memperoleh nilai tertinggi 18 pada pelaksanaan rembug di Desa Cilangkap adalah pembangunan sarana pendidikan TK dan SD dan pembangunan sarana air minum di Kampung Lebak Jaha, pembangunan jembatan penghubung antar kampung di Kampung Cisujen dan pembangunan gardu listrik di Kampung Dongdong. Kemudian nilai kebutuhan dan usulan kegiatan yang mendapatkan peringkat kedua, ketiga dan keempat dengan masing-masing nilai sebanyak 17, 16 dan 15 adalah pembangunan akses jalan penghubung di Kampung Sawah, pembangunan sarana kantor desa di Kampung Warung Jogjog dan pembangunan jalan telford di Kampung Sukasari 1. Selanjutnya nilai kebutuhan dan usulan kegiatan yang mendapatkan peringkat kelima dan keenam dengan masingmasing nilai sebanyak 14 adalah pembangunan MCK di Kampung Sukasari 2 dan pembangunan jalan paving block di Kampung Ciparaha. Sedangkan nilai kebutuhan dan usulan kegiatan yang mendapatkan peringkat ketujuh dan kedelapan dengan masing-masing nilai 12 adalah pembangunan jembatan penghubung di kampung Pematang Karet dan pembangunan drainase di kampung Cikaredok

Dari hasil pemetaan perencanaan pembangunan yang dilakukan berdasarkan aspek penilaian dari analisis kebutuhan dan usulan kegiatan di atas dapat disimpulkan bahwa perencanaan pembangunan yang akan dilakukan adalah sebagai berikut:

Volume 1, Number 2, November 2017| 235 Pemberday aan Masyarakat melalui Inovasi Perencanaan Pembangunan berbasis 4R (Rembug, Rencana, Realisasi dan Rawat) di Desa Cilangkap Kecamatan Wanas alam sebagai Pilar Utama Kebijakan Partisipatif dan Go tong Royong 
Tabel 13. Analisis prioritas, peringkat dan waktu Perencanaan Pembangunan

\begin{tabular}{|c|c|c|c|}
\hline No & $\begin{array}{l}\text { Analisis prioritas } \\
\text { Kebutuhan usulan kegiatan }\end{array}$ & Peringkat & $\begin{array}{l}\text { Waktu perencanaan } \\
\text { Pembangunan }\end{array}$ \\
\hline 1 & Pembangunan jalan telford & 4 & Tahun kedua \\
\hline 2 & Pembangunan MCK bagi masyarakat yang belum memiliki & 5 & Tahun ketiga \\
\hline 3 & Pembangunan Jembatan penghubung & 8 & Tahun keempat \\
\hline 4 & $\begin{array}{l}\text { Pembangunan sarana pendidikan } \\
\text { pembangunan sarana air minum }\end{array}$ & 1 & Tahun pertama \\
\hline 5 & Pembangunan sarana kantor desa & 3 & Tahun kedua \\
\hline 6 & Pembangunan drainase & 7 & Tahun keempat \\
\hline 7 & Pembangunan Jalan paving block & 6 & Tahun ketiga \\
\hline 8 & Pembangunan jembatan & 1 & Tahun pertama \\
\hline 9 & Pembangunan gardu listrik & 1 & Tahun pertama \\
\hline 10 & Pembangunan jalan akses penghubung & 2 & Tahun kedua \\
\hline
\end{tabular}

Dari tabel di atas, maka dapat disimpulkan bahwa perencanaan pembangunan yang akan dilakukan di tahun pertama terdapat tiga kegiatan yaitu pembangunan sarana pendidikan TK dan SD serta pembangunan sarana air minum, pembangunan jembatan dan pembangunan gardu listrik. Pada tahun kedua akan direncanakan pembangunan jalan telford, pembangunan sarana kantor desa dan pembangunan jalan akses penghubung antar dusun. Kemudian pada tahun ketiga akan direncanakan pembangunan MCK dan pembangunan jalan paving block. Sedangkan pada tahun keempat perencanaan pembangunan akan diprioritaskan pada pembangunan jembatan penghubung dan pembangunan saluran drainase.

\section{Rencana}

Pada intinya rencana mencakup tentang perencanaan pembangunan masyarakat yang telah disepakati dan diusulkan dalam bentuk rencana kegiatan perencanaan pembangunan masyarakat yang akan disampaikan dalam Musyawarah Perencanaan Pembangunan (Musrenbang) Desa.

Pada tahap rencana ini, ditetapkan rencana pembangunan berbasis partisipatif dan gotong royong. Perencanaan pembangunan partisipatif dan gotong royong yang disepakati mencakup hal-hal sebagai berikut:

- Pengukuran lokasi pembangunan

- Pengaturan tenaga kerja (jumlah tenaga kerja, calon tenaga kerja dan besaran upah);

- Pengaturan bahan dan alat yang akan digunakan;

- Pengaturan waktu pencapaian.

Volume 1, Number 2, November 2017 | 1 Pemberday aan Masyarakat m elalui Inovasi Perencanaan Pembangunan berbasis 4R (Rembug, Renc ana, Realisasi dan Rawat) di Desa Cilangkap Kecamatan Wanasalam sebagai Pilar Utama Kebijakan Partisipatif dan Gotong Royong 

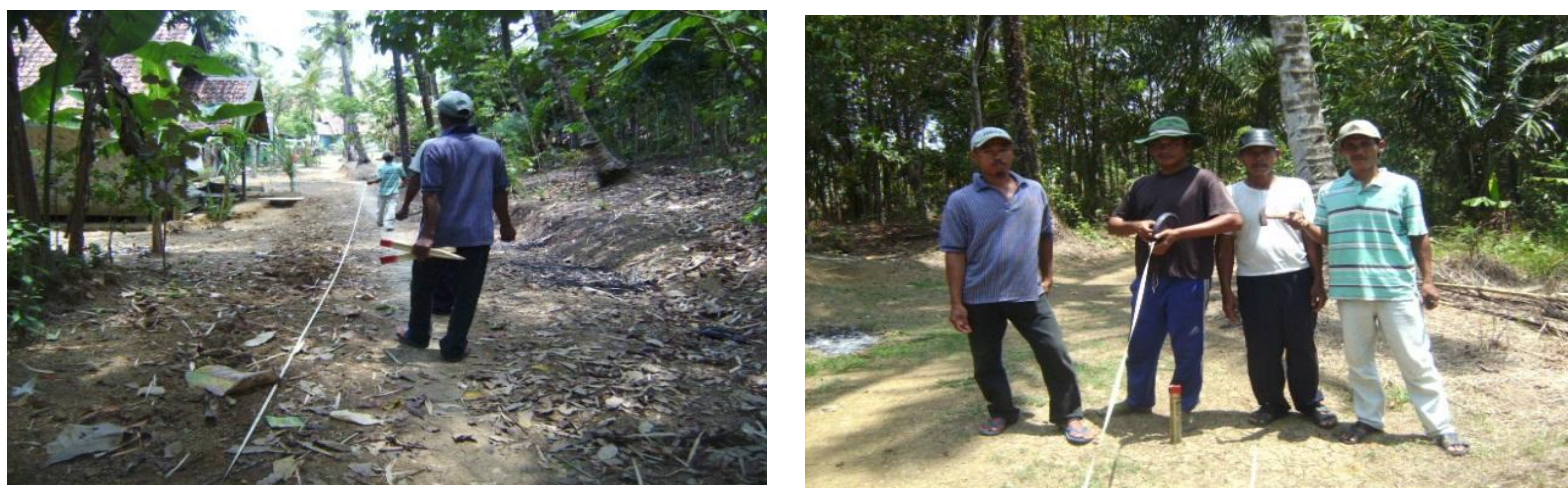

Gambar 10. Pengukuran Lokasi Pembangunan

\section{Realisasi}

- Tahap realisasi pekerjaan dilakukan oleh masyarakat setempat secara partisipatif dan gotong royong

- Keterlibatan masyarakat diperlukan sebagai bagian dari komitmen bersama masyarakat

- Apabila realisasi pembangunan dilakukan di dusun 1, maka aktor utama pembangunan adalah masyarakat dusun 1 dan didukung oleh masyarakat dusun sekitarnya.

- Pada tahap ini, penting untuk memastikan bahwa rencana kegiatan pembangunan diakomodir dalam musyawarah perencanaan pembangunan (Musrenbang) Desa oleh karena itu masyarakat berperan secara aktif dalam forum Musrenbang tersebut

\section{Rawat}

Pada tahap ini masyarakat adalah aktor penerima manfaat dari pembangunan yang telah dilaksanakan sehingga perannya dalam melakukan pemeliharaan atau merwat hasil pembangunan sangatlah penting.

\section{Kesimpulan dan Saran}

Dari pendampingan yang telah dilaksanakan, dapat disimpulkan beberapa hal sebagai berikut:

Masyarakat Desa Cilangkap sebagai mitra pengabdian masyarakat memiliki respon dan antusias yang sangat besar dalam proses pendampingan perencanaan pembangunan. Hal tersebut dapat terlihat dari jumlah kehadiran masyarakat dalam forum rembug warga kampung dengan jumlah kehadiran rata-rata sebesar 60\% dari total jumlah KK di setiap kampung.

Sebagai salah satu desa yang sebagian besar masih tergolong kurang sejahtera/miskin, antusias masyarakat dalam mengikuti program pendampingan perlu mendapatkan apresiasi

Volume 1, Number 2, November $2017 \mid 2$ Pemberday aan Masyarakat melalui Inovasi Perencanaan Pembangunan berbasis 4R (Rembug, Renc ana, Realisasi dan Rawat) di Desa Cilangkap Kecamatan Wanasalam sebagai Pilar Utama Kebijakan Partisipatif dan Gotong Royong 
sebagai bagian dari upaya kesadaran masyarakat tentang pentingnya pembangunan yang dirancang dari, oleh dan untuk masyarakat.

Kemampuan masyarakat dalam merancang perencanaan pembangunan melalui kegiatan pembentukan organisasi perencana pembangunan, kegiatan survey kampung mandiri dan kegiatan rembug, rencana, realiasi dan rawat dapat dijalankan dengan baik walaupun dengan segala keterbatasan yang dimiliki akan tetapi tidak mengurangi substansi dari tumbuhnya proses pemberdayaan masyarakat dan motivasi masyarakat dalam kegiatan perencanaan pembangunan tersebut.

Adapun saran-saran dalam kegiatan ini adalah:

1. Diperlukan instrumen kontrol dan evaluasi dalam setiap perencanaan pembangunan perdesaan. Fungsi tersebut dapat dilakukan melalui sinerginya semua pihak dalam pemberdayaan masyarakat.

2. Dalam mendorong perencanaan pembangunan yang efektif, maka diperlukan pendekatan pemberdayaan yang dilaksanakan secara berkelanjutan sebagai solusi efektif sebagai upaya untuk mendorong implementasi pembangunan berkelanjutan dengan menempatkan masyarakat sebagai Subjek dalam penyelenggaraan program melalui proses pemberdayaan dan pembangunan partisipatif.

3. Tindak lanjut solusi guna mengatasi permasalahan memerlukan dukungan dan partisipasi dari semua pihak yang terlibat baik dari jajaran top down maupun bottom up, masyarakat selaku front line perencanaan pembangunan sejatinya dapat diikutsertakan secara aktif terutama kaum perempuan dan masyarakat miskin.

\section{Daftar Referensi}

Appel, K., Buckingham, E Jodoin, K., and D. Roth. Participatory Learning and Action Toolkit: For Application in BSR's Global Programs. Paris: BSR, 2012.

Hasbullah, J. Social Capital. Jakarta: United Press, 2006.

Phuyal, K. "Participatory Learning and Action [PLA]: A Brief Introduction."

Presiden Republik Indonesia. Undang-Undang Nomor6 Tabun 2014 Tentang Desa. Indonesia, 2014.

T, Mardikanto, and Soebiato P. Pemberdayaan Masyarakat Dalam Perspektif Kebijakan Publik.

Bandung: Alfabeta, 2013.

Theresia, Aprillia, and et all. Pembangunan Berbasis Masyarakat. Bandung: Alfabeta, 2104.

Volume 1, Number 2, November 2017|3

Pemberday aan Masyarakat melalui Inovasi Perencanaan Pembangunan berbasis 4R (Rembug, Renc ana, Realisasi dan Rawat) di Desa Cilangkap Kecamatan Wanasalam sebagai Pilar Utama Kebijakan Partisipatif dan Gotong Royong 